\title{
Turnout, Tenuousness, and Getting Results in Section 2 Vote Denial Claims
}

\author{
PAMELA S. KARLAN*1 \\ TABLE OF CONTENTS
}

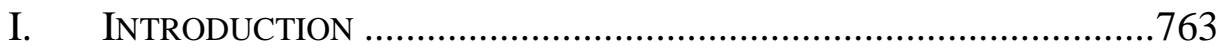

II. THE LEGAL SIGNIFICANCE OF TURNOUT ....................................768

III. THE LEGAL SignifICANCE OF CHANGE.....................................777

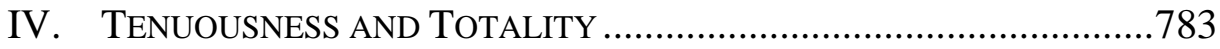

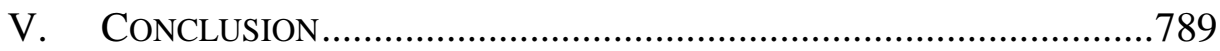

\section{INTRODUCTION}

Voting rights jurisprudence is a story of courts seeking judicially manageable standards for entering the political thicket. In Baker v. Carr, for example, the Supreme Court insisted that "well developed and familiar" judicial standards had been available to courts "since the enactment of the Fourteenth Amendment" for adjudicating claims of legislative malapportionment. ${ }^{2}$ Yet two years later, the Court replaced any inquiry into whether, "on the particular facts," an apportionment was "arbitrary and capricious"3 (a fairly conventional yardstick) with a universal requirement of one-person, one-vote ${ }^{4}$ - a "rigidly numerical standard" like nothing "anywhere

* Kenneth and Harle Montgomery Professor of Public Interest Law and Co-Director, Supreme Court Litigation Clinic, Stanford Law School.

${ }^{1}$ Long ago, Justice Holmes stated that "it is required of a man that he should share the passion and action of his time at peril of being judged not to have lived." OLIVER Wendell Holmes, Memorial Day (May 30, 1884), in The OcCasional Speeches of Justice Oliver Wendell Holmes 4, 6-7 (Mark DeWolfe Howe ed., 1962). Of a woman too. During 2014 and 2015, as a Deputy Assistant Attorney General in the Civil Rights Division of the U.S. Department of Justice, I shared the passion and action of my time with the extraordinary lawyers in the Division's front office and in the Voting and Appellate Sections. I worked on several of the cases discussed in this Article, particularly North Carolina State Conference of NAACP v. McCrory, 831 F.3d 204 (4th Cir. 2016); Veasey v. Abbott, 830 F.3d 216 (5th Cir. 2016) (en banc); League of Women Voters of North Carolina v. North Carolina, 769 F.3d 224 (4th Cir. 2014); and Ohio State Conference of NAACP v. Husted, 768 F.3d 524 (6th Cir. 2014). My views are my own but they were powerfully shaped by those colleagues' many insights as well as by discussions with my three co-authors-Sam Issacharoff, Rick Pildes, and Nate Persily-as we revised the chapters of our casebook, SAMUEl ISSACHAROFF, PAMELA S. KARLAN, RichARD H. PILDES \& Nathaniel Persily, The LaW of Democracy: Legal Structure of the Political PROCESS (5th ed. 2016) [hereinafter THE LAW OF DEMOCRACY], to respond to the issues discussed here.

2 Baker v. Carr, 369 U.S. 186, 226 (1962).

${ }^{3}$ Id.

${ }^{4}$ Reynolds v. Sims, 377 U.S. 533, 577 (1964) (imposing the requirement on state legislative apportionments). The requirement for equipopulous districting was applied to 
else in constitutional law." 5 So, too, with respect to claims of racial discrimination under the Voting Rights Act. In section 5 of the Act, Congress forbid covered jurisdictions from making changes to their election laws unless they could show that the new law had neither a discriminatory purpose nor a discriminatory effect. ${ }^{6}$ The Court narrowed the focus to whether there had been retrogression, turning the prior practice into a clear, exclusive baseline against which to compare the new measure. ${ }^{7}$ Similarly, in section 2 of the Act, Congress forbid jurisdictions nationwide from using voting-related practices or procedures that, under "the totality of circumstances," result in the political process not being "equally open" to participation by minority citizens. ${ }^{8}$ The Senate Report accompanying the codification of this results test had identified nine "[t]ypical factors" that might have "probative value" in making this determination. ${ }^{9}$ It squarely cautioned that "there is no requirement that any

congressional districting plans in Wesberry v. Sanders, 376 U.S. 1, 18 (1964), and to all other elected bodies exercising general governmental powers in a series of cases beginning with Avery v. Midland County, 390 U.S. 474, 484-85 (1968).

${ }^{5}$ Pamela S. Karlan, Exit Strategies in Constitutional Law: Lessons for Getting the Least Dangerous Branch Out of the Political Thicket, 82 B.U. L. REV. 667, 671 (2002); see also Pamela S. Karlan, Answering Questions, Questioning Answers, and the Roles of Empiricism in the Law of Democracy, 65 STAN. L. REV. 1269, 1272-73 (2013) [hereinafter Karlan, Answering Questions] (discussing the emergence of one-person, one-vote); $c f$. John Hart Ely, DEMOCRACY AND Distrust: A THEORY OF Judicial REVIEW 121 (1980) (stating, of one-person, one-vote, that "administrability is its long suit, and the more troublesome question is what else it has to recommend it").

652 U.S.C. \$ 10304 (Supp. II 2014).

${ }^{7}$ See Beer v. United States, 425 U.S. 130, 141 (1976). Several members of the Court emphasized the special clarity of that benchmark in a decision refusing to subject the size of a jurisdiction's elected body to scrutiny under section 2 of the Voting Rights Act, now codified at 52 U.S.C. $\S 10301$, even though changes to the size of such a body are subject to the preclearance requirement of section 5. See Holder v. Hall 512 U.S. 874, 880 (1994) (plurality opinion) (describing the need in section 2 suits to "find a reasonable alternative practice as a benchmark against which to measure the existing voting practice"). For discussion of how, over time, the Court limited the substantive reach of section 5 "entirely to preventing "backsliding," see Michael Halberstam, The Myth of "Conquered Provinces": Probing the Extent of the VRA's Encroachment on State and Local Autonomy, 62 HASTINGS L.J. 923, 981 (2011). For a discussion of the benefits and drawbacks of nonretrogression standards more generally, see John C. Jeffries, Jr. \& Daryl J. Levinson, The Non-Retrogression Principle in Constitutional Law, 86 CALIF. L. REV. 1211 (1998).

852 U.S.C. $\$ 10301(\mathrm{~b})$.

${ }^{9}$ S. REP. No. 97-417, at 28-29 (1982); see also Thornburg v. Gingles, 478 U.S. 30, 43-44, 43 n.7 (1986). The Supreme Court relied heavily on the Senate Report in its foundational section 2 opinion in Gingles, see id. at $43 \mathrm{n} .7$, and virtually every judicial opinion addressing a section 2 claim discusses the Senate Report factors. The nine factors are:

1. [T] he extent of any history of official discrimination in the state or political subdivision that touched the right of the members of the minority group to register, to vote, or otherwise to participate in the democratic process; 
particular number of factors be proved, or that a majority of them point one way or the other." 10 But in Thornburg v. Gingles, the Court superimposed a threshold test for racial vote dilution claims with three "necessary preconditions" that rest on essentially objective inquiries. ${ }^{11}$ The first Gingles factor asks whether it is cartographically possible to draw a single-member district in which members of the minority group "constitute a majority;" 12 this requirement was later further refined into "an objective, numerical test: Do minorities make up more than 50 percent of the voting-age population in the relevant geographic area?"13 The second and third Gingles factors turn on whether there is racially polarized voting and whether, as a result, the minority community's preferred candidates usually lose ${ }^{14}$-questions answered essentially through quantitative analyses of election data. ${ }^{15}$

2. [T]he extent to which voting in the elections of the state or political subdivision is racially polarized;

3. [T] he extent to which voting in the elections of the state or political subdivision has used unusually large election districts, majority vote requirements, anti-single shot provisions, or other voting practices or procedures that may enhance the opportunity for discrimination against the minority group;

4. [I]f there is a candidate slating process, whether the members of the minority group have been denied access to that process;

5. [T] he extent to which members of the minority group in the state or political subdivision bear the effects of discrimination in such areas as education, employment and health, which hinder their ability to participate effectively in the political process;

6. [W] hether political campaigns have been characterized by overt or subtle racial appeals;

7. [T] he extent to which members of the minority group have been elected to public office in the jurisdiction[;]

... [8.] [W]hether there is a significant lack of responsiveness on the part of elected officials to the particularized needs of the members of the minority group[; and]

[9.] [W] hether the policy underlying the state or political subdivision's use of such voting qualification, prerequisite to voting, or standard, practice or procedure is tenuous.

S. REP. No. 97-417, at 28-29 (footnotes omitted).

${ }^{10}$ S. REP. No. 97-417, at 29.

11 Gingles, 478 U.S. at 50.

12 Id.

13 Bartlett v. Strickland, 556 U.S. 1, 18 (2009); see Halberstam, supra note 7, at 987 (tying together the Reapportionment Cases and Bartlett v. Strickland as places where "the Court insisted on imposing 'mathematically administrable' bright-line rules justified by reference to purportedly self-evident, geometrical principles of democracy”).

14 Gingles, 478 U.S. at 52-53.

${ }^{15}$ For discussions of this "quantitative turn," see Karlan, Answering Questions, supra note 5, at 1275-78, and Samuel Issacharoff, Polarized Voting and the Political Process: The Transformation of Voting Rights Jurisprudence, 90 MiCH. L. REV. 1833, 1859-60, 1866-69 (1992) [hereinafter Issacharoff, Polarized Voting]. For an accessible discussion of the actual social scientific methods, see THE LAW OF DEMOCRACY, supra note 1, at 805-14. For discussion of the continuing imperative to develop bright-line commands and 
In recent years, courts have been called on to adjudicate claims involving what Dan Tokaji dubbed "the new vote denial"16 - practices that prevent individuals from casting a ballot or having that ballot counted. ${ }^{17}$ The upsurge in cases claiming vote denial (as opposed to vote dilution) is the product of a confluence of forces. The Voting Rights Act's preclearance regime, which had largely "stopped would-be vote denial from occurring in covered jurisdictions,"18 effectively disappeared after the Supreme Court's decision in Shelby County v. Holder ${ }^{19}$ held the coverage formula unconstitutional. ${ }^{20}$ And increased partisan polarization, combined with understandings about the "empirical relation between turnout and election outcomes," produced a spate of measures in which Republican officials cut back on expansions to voting opportunities previously implemented by Democrats. ${ }^{21}$

prohibitions, see Richard H. Pildes, Is Voting-Rights Law Now at War with Itself? Social Science and Voting Rights in the 2000s, 80 N.C. L. REV. 1517, 1556 (2002), and Daniel P. Tokaji, Applying Section 2 to the New Vote Denial, 50 HARV. C.R.-C.L. L. REV. 439, 463 (2015) [hereinafter Tokaji, Applying Section 2].

${ }^{16}$ Daniel P. Tokaji, The New Vote Denial: Where Election Reform Meets the Voting Rights Act, 57 S.C. L. REV. 689, 691-92 (2006) [hereinafter Tokaji, New Vote Denial]. For other important scholarship on the new vote denial, see generally Dale E. Ho, Voting Rights Litigation After Shelby County: Mechanics and Standards in Section 2 Vote Denial Claims, 17 N.Y.U. J. LeGIS. \& PUB. POL'Y 675 (2014); Janai S. Nelson, The Causal Context of Disparate Vote Denial, 54 B.C. L. REV. 579 (2013); and Tokaji, Applying Section 2, supra note 15.

${ }^{17}$ The Voting Rights Act expressly includes both "casting a ballot, and having such ballot counted properly and included in the appropriate totals of votes cast" in its definition of "voting." 52 U.S.C. $§ 10310$ (c)(1) (Supp. II 2014). I highlight that point because a later federal statute, the Help America Vote Act, requires that election officials provide a provisional ballot to any individual who declares that he or she is a registered voter if that person's name does not appear on the list of eligible voters for that polling place, but leaves to state law the question whether to count that ballot. 52 U.S.C. § 21082(a)(4). This uncertainty has produced a significant amount of litigation. See, e.g., Sandusky Cty. Democratic Party v. Blackwell, 387 F.3d 565, 578 (6th Cir. 2004); Daniel P. Tokaji, Early Returns on Election Reform: Discretion, Disenfranchisement, and the Help America Vote Act, 73 GEO. WASH. L. REV. 1206, 1228-34 (2005). 2014).

${ }^{18}$ League of Women Voters of N.C. v. North Carolina, 769 F.3d 224, 239 (4th Cir.

${ }^{19}$ Shelby Cty. v. Holder, 133 S. Ct. 2612 (2013).

${ }^{20}$ Id. at 2631. Section 3(c) of the Voting Rights Act, 52 U.S.C. $\$ 10302$ (c), authorizes courts that find violations of the Fourteenth or Fifteenth Amendments in the course of adjudicating either statutory or constitutional voting-rights claims to place jurisdictions under an obligation to preclear voting-related changes. For discussions of that provision, which has been imposed infrequently (at least so far), see THE LAW OF DEMOCRACY, supra note 1, at 766-67, and Travis Crum, The Voting Rights Act's Secret Weapon: Pocket Trigger Litigation and Dynamic Preclearance, 119 YALE L.J. 1992, 1997-98, 2006-17 (2010).

21 THE LAW OF DEMOCRACY, supra note 1, at 124; see also RICHARD L. HASEN, THE Voting WARs: From Florida 2000 to the NeXt Election Meltdown (2012) (discussing the increased partisanship in election administration); Samuel Issacharoff, Ballot Bedlam, 64 DuKE L.J. 1363, 1370 (2015) [hereinafter Issacharoff, Ballot Bedlam] 
How should courts analyze these claims? Recently, the courts of appeals have begun to coalesce on a two-part framework: First, the challenged practice "must impose a discriminatory burden on members of a protected class, meaning that members of the protected class 'have less opportunity than other members of the electorate to participate in the political process and to elect representatives of their choice." 22 Second, "that burden must in part be caused by or linked to 'social and historical conditions' that have or currently produce discrimination against members of the protected class." 23 The courts' insistence that "[i]n assessing both elements, courts should consider "the totality of circumstances," 24 and should be informed by the Senate Report's nine "typical' factors" 25 is an important gloss on the emerging framework, which otherwise might render virtually every electoral rule vulnerable in any jurisdiction where registration or turnout rates differ by race and plaintiffs can identify some potential improvement to the system that would reduce that disparity. The emerging framework explicitly incorporates the fifth of the Senate Report factors: "[T] in the state or political subdivision bear the effects of discrimination in such areas as education, employment and health, which hinder their ability to participate effectively in the political process ...."26 But the gloss raises the

(stating that in the contemporary politically polarized environment, "the single predictor necessary to determine whether a state will impose voter-access restrictions is whether Republicans control the ballot-access process"). For discussion of this dynamic in North Carolina and Wisconsin, see, respectively, North Carolina State Conference of NAACP $v$. McCrory, 831 F.3d 204, 226-27 (4th Cir. 2016), and One Wisconsin Institute v. Thomsen, 15-cv-324-jdp, 2016 WL 4059222, at*16-17, *21, *23-25 (W.D. Wis. July 29, 2016).

22 Ohio State Conf. of NAACP v. Husted, 768 F.3d 524, 554 (6th Cir. 2014) (quoting section 2(b) of the Voting Rights Act, now codified at 52 U.S.C. 10301(b)); accord Veasey v. Abbott, 830 F.3d 216, 244 (5th Cir. 2016) (en banc) ("We now adopt the two-part framework employed by the Fourth and Sixth Circuits ...."); League of Women Voters, 769 F.3d at 240 ("[W]e agree with the Sixth Circuit that a Section 2 vote-denial claim consists of two elements.").

${ }^{23}$ Ohio State Conf., 768 F.3d at 554 (quoting Thornburg v. Gingles, 478 U.S. 30, 47 (1986)).

${ }^{24}$ Id. (quoting section 2(b) of the Voting Rights Act, now codified at 52 U.S.C. 10301(b)); accord League of Women Voters, 769 F.3d at 240 (quoting Ohio State Conf., 768 F.3d at 554).

${ }^{25}$ League of Women Voters, 769 F.3d at 240, 245 (stating that "consideration of the 'typical' factors" listed in the Senate Report "may shed light on whether the two elements of a Section 2 [vote denial] claim are met"); accord Veasey, 830 F.3d at 245 (concluding, "[a]s did the Fourth and Sixth Circuits," that the Senate Report factors (which the court of appeals mislabeled as "the Gingles factors") "should be used to help determine whether there is a sufficient causal link between the disparate burden imposed and social and historical conditions produced by discrimination").

${ }^{26}$ S. REP. No. 97-417, at 29 (1982). 
question of how the Senate Report factors-distilled as they were from cases involving vote dilution ${ }^{27}$ — should apply to vote denial claims.

This Article "provide[s] some structure to the statute's 'totality of circumstances' test" in vote denial cases. ${ }^{28}$ First, neither an actual nor a predicted decrease in minority turnout should serve as a necessary precondition to a section 2 results claim alleging vote denial. There are theoretical, doctrinal, and practical reasons for treating election results as a relatively minor consideration with respect to the discriminatory burden prong of the emerging framework. If anything, data or predictions about turnout effects are more relevant to the question whether the challenged practice is tainted by an impermissible purpose than they are to determining the existence of a discriminatory burden.

Second, courts in section 2 vote denial cases should be guided by the Voting Rights Act's overall commitment to expanding the opportunity for minority citizens to participate in the political process. Particularly when confronted with a challenge involving a provision that reduces preexisting opportunities to vote, courts should not hesitate to find that the new provision constitutes a "burden" under the emerging framework. Giving evidentiary weight to the existence of a change does not impermissibly import the retrogression standard of section 5 into section 2 .

Third, whether the policy underlying the challenged practice is "tenuous" (the final Senate Report factor) of necessity plays a more central role in vote denial cases than it has in vote dilution cases. This does not transform the results test into a purpose inquiry; rather, it is a question of the fit between the policy and the burden. The strength of the government's proffered policy justifications goes to the heart of whether the practice imposes a burden and whether that burden is discriminatory. More particularly, in vote denial cases, partisan motivations, regardless of whether they rise to the level of an independent constitutional violation or suffice to prove a racially discriminatory purpose, are tenuous as a matter of law and should impose a burden of justification on a defendant jurisdiction.

\section{THE LEGAL SigNIFICANCE OF TURNOUT}

The right to vote embodies a nested constellation of concepts: the ability to cast a ballot and have that ballot counted (what I call "voting as participation" 29 ); the use of fair rules to determine election winners (what I

${ }^{27} I d$. at 28 n.113 (explaining that the factors were "derived" from White v. Regester, 412 U.S. 755 (1973), and Zimmer v. McKeithan, 485 F.2d 1297 (5th Cir. 1973), two cases involving claims that multimember districts diluted the voting strength of minority communities).

28 Johnson v. De Grandy, 512 U.S. 997, 1010 (1994) (describing Gingles as having done this for challenges to multi-member electoral districts).

${ }^{29}$ Pamela S. Karlan, The Rights to Vote: Some Pessimism About Formalism, 71 TeX. L. REV. 1705, 1709-12 (1993) [hereinafter Karlan, The Rights to Vote]. 
call "voting as aggregation" 30 and Dan Tokaji terms, more concretely with respect to section 2 dilution claims, a "representation" right ${ }^{31}$ ); and effective inclusion in post-electoral decisionmaking through elected officials (what I call "voting as governance"32). The linchpin of Gingles and the stream of section 2 racial vote dilution lawsuits that followed was a claim that even if minority voters could cast a ballot and have that ballot counted, the aggregation rules being used - the use of multimember districts or the configuration of single-member districts-resulted in the minority community's preferred representatives being defeated. Put simply, those section 2 "results" claims necessarily turn on election results. As long as a minority community has "sustained success" 33 at the polls, members of the minority group do not suffer racial vote dilution cognizable under section 2. ${ }^{34}$ Indeed, the totality-of-the-circumstances factor that appears expressly in section 2 itself is " $t \mathrm{t}] \mathrm{he}$ extent to which members of a protected class have been elected to office in the State or political subdivision" whose electoral practices are being challenged. ${ }^{35}$

In contrast to vote dilution claims, which necessarily look at election outcomes, an "essential feature" of participation-based voting rights claims is that they are "wholly outcome-independent." 36 It is no answer to a citizen's claim that she was improperly prevented from casting her ballot that the candidates she prefers are unlikely to win. ${ }^{37}$ Nor is it an answer to an aspiring

${ }^{30} I d$. at $1712-17$.

${ }^{31}$ Tokaji, Applying Section 2, supra note 15, at 442 (emphasis omitted).

32 Karlan, The Rights to Vote, supra note 29, at 1716-19.

33 Thornburg v. Gingles, 478 U.S. 30, 77 (1986).

${ }^{34}$ The one exception would be if members of the racial group were purposefully packed into overpopulated districts. $C f$. Harris v. Ariz. Indep. Redistricting Comm'n, 136 S. Ct. 1301, 1309-10 (2016) (rejecting a claim that a less than 10\% underpopulation of majority-minority legislative districts violated one-person, one-vote). Violations of oneperson, one-vote implicate governance interests because even though members of the group are able to elect the representatives of their choice, once those elected representatives arrive in the legislature, they can be outvoted by legislators representing fewer constituents. See Karlan, The Rights to Vote, supra note 29, at 1717. If minority voters were deliberately placed in overpopulated districts for the purpose of reducing minority political strength, this would violate section 2's prohibition on intentional racial vote dilution as well as the Fourteenth Amendment's prohibitions on both purposeful racial discrimination and quantitative malapportionment.

3552 U.S.C. $§ 10301$ (b) (Supp. II 2014). The seventh of the Senate Report's typical factors is "the extent to which members of the minority group have been elected to public office in the jurisdiction." S. REP. NO. 97-417, at 29 (1982).

${ }^{36}$ Karlan, The Rights to Vote, supra note 29, at 1710.

${ }^{37}$ A powerful illustration of this point involved an election conducted on the eve of the Voting Rights Act's passage. The Fifth Circuit threw out the results because the jurisdiction had used racially segregated voting booths. Bell v. Southwell, 376 F.2d 659, 659-60 (5th Cir. 1967). It distinguished "such indefensible, racial distinctions" from "the usual simple case of counting votes and denying relief for want of affirmative proof of a different result." Id. at 664-65; see also Christopher S. Elmendorf, Making Sense of 
voter's exclusion from the polls that her vote would have been superfluous. ${ }^{38}$ "[T] he right to vote is personal ...."39 Indeed, section 2 expressly provides that no voting practice can be imposed or applied "in a manner which results in a denial or abridgement of the right of any citizen" in the singular "to vote." 40

To be sure, when it comes to a vote denial claim under section 2, courts must look beyond the individual plaintiff's status as a citizen and aspiring voter to consider whether the denial of the right to vote was "on account of race or color" or membership in a protected language minority group (as opposed to on some other basis). ${ }^{41}$ Not every denial of the right to vote violates section 2 . The first element of the emerging test requires that the plaintiff show a tangible burden that disproportionately affects minority citizens, an inherently group-focused inquiry. But the necessity of a plaintiff's proving that she is part of a racially identifiable group to which the political processes are not "equally open" 42 and that the inequality is causally connected to group membership should not shift the focus to election outcomes. Indeed, Justice Scalia, who generally read the Voting Rights Act as narrowly as it was humanly possible to do, once explained:

If, for example, a county permitted voter registration for only three hours one day a week, and that made it more difficult for blacks to register than whites, blacks would have less opportunity "to participate in the political process" than whites, and $\S 2$ would therefore be violated-even if the number of potential black voters was so small that they would on no hypothesis be able to elect their own candidate. ${ }^{43}$

Section 2: Of Biased Votes, Unconstitutional Elections, and Common Law Statutes, $160 \mathrm{U}$. PA. L. REV. 377, 404 n.126 (2012) ("Participation injuries may, but need not, result in actionable vote dilution.").

${ }^{38}$ Cf. Nicholas O. Stephanopoulos \& Eric M. McGhee, Partisan Gerrymandering and the Efficiency Gap, 82 U. CHI. L. REV. 831, 834 (2015) (noting that a vote can be said to have been wasted "if it is cast (1) for a losing candidate, or (2) for a winning candidate but in excess of what she needed to prevail"). It is, of course, extraordinarily unlikely that any person's vote will directly change the outcome of an election. Paul E. Meehl, The Selfish Voter Paradox and the Thrown-Away Vote Argument, 71 AM. PoL. SCI. REV. 11, 30 (1977).

${ }^{39}$ Reynolds v. Sims, 377 U.S. 533, 561 (1964) (quoting United States v. Bathgate, 246 U.S. 220, 227 (1918)). If an individual is "that much less a citizen" to the extent that his vote "is debased," $i d$. at 567 , how much even less is he a citizen if his right to vote is denied altogether?

4052 U.S.C. $\S 10301(\mathrm{a})$.

${ }^{41} I d$. The protected language minority groups - "persons who are American Indian, Asian American, Alaskan Natives or of Spanish heritage"-are identified in 52 U.S.C. $\S 10310(\mathrm{c})(3)$.

42 Id. § 10301(b).

${ }^{43}$ Chisom v. Roemer, 501 U.S. 380, 408 (1991) (Scalia, J., dissenting) (citation omitted). I represented the private petitioners in that case. 
It is easy to see why courts might be tempted to look to turnout as the way to figure out whether a particular practice imposes a discriminatory burden. Certainly, there are cases where turnout disparities might be enough, standing alone, to satisfy that element of the emerging test. Consider an historical example: Morgan Kousser has estimated that Georgia's imposition of a poll tax during Redemption reduced overall white turnout by somewhere between $16 \%$ and $28 \%$ and overall black turnout by roughly half. ${ }^{44}$ Had the Georgia tax been challenged under section 2, a reviewing court should have concluded that the tax imposed a discriminatory burden. That the tax was burdensome would have been shown by comparing turnout before and after its imposition: the tax by definition raised the cost of voting and, not surprisingly, that increase in cost led significant numbers of otherwise eligible citizens to forgo casting a ballot. The poll tax formally burdened both black and white potential voters. ${ }^{45}$ But that the burden was discriminatory would have been shown by the fact that significantly more black potential voters than white ones did not vote after the tax was imposed. (The plaintiffs in this hypothetical section 2 case would certainly have satisfied the linkage prong of the emerging framework as well: black Georgians, as a result of slavery and pervasive racial discrimination from the time of Emancipation forward, were poorer than the state's white residents and therefore had both fewer resources from which to pay the poll tax and more need to use those resources elsewhere. ${ }^{46}$ ) Evidence of a relatively higher actual decline in minority turnout linked to a challenged practice might therefore be sufficient to find that a plaintiff had established a discriminatory burden under the first prong of the emerging test.

But proof of a racially disproportionate effect on turnout cannot be necessary to establishing a section 2 violation. First, turnout data cannot be gathered until after there has been an election. Section 2 does not require that plaintiffs wait until after they have been denied the right to vote in at least one election cycle before they can challenge a restriction. To the contrary: part of the reason the Supreme Court insisted that preclearance is no longer necessary is that under section 2 "injunctive relief is available in appropriate cases to block voting laws from going into effect." 47 Particularly because "any illegal

44 J. Morgan Kousser, The Shaping of Southern Politics: Suffrage RESTRICTION AND THE ESTABLISHMENT OF THE ONE-PARTY SOUTH, 1880-1910, at 67-68 (1974).

45 This assumes, of course, that the tax was fairly imposed on everyone. With respect to many of the disenfranchising devices used in the century prior to passage of the Voting Rights Act, particularly literacy tests and understanding provisions, this was not the case: discriminatory administration was also a substantial problem. See United States v. Louisiana, 225 F. Supp. 353, 382-84 (E.D. La. 1963) (three-judge court) (discussing evidence of this discriminatory administration in Louisiana), aff'd, 380 U.S. 145 (1965).

46 See KOUSSER, supra note 44, at 64-67 (discussing how the interaction between poverty, the sharecropping economy, and the poll tax depressed voter turnout).

${ }^{47}$ Shelby Cty. v. Holder, 133 S. Ct. 2612, 2619 (2013). Section 12(d) of the Voting Rights Act authorizes the United States to seek "preventative relief," including a "permanent injunction” for section 2 violations. 52 U.S.C. $§ 10308(d)$. 
impediment to the right to vote, as guaranteed by the U.S. Constitution or statute, would by its nature be an irreparable injury," 48 courts cannot impose a requirement that plaintiffs show that the challenged practice has actually reduced turnout.

The Voting Rights Act's expansive definition of voting - which reaches "all action necessary to make a vote effective" and expressly includes "registration ... or other action required by law prerequisite to voting, casting a ballot, and having such ballot counted properly and included" 49 _reinforces the conclusion that practices that screen out a disproportionate percentage of minority citizens at the registration stage (such as cutbacks in same-day registration or documentation requirements) or at the ballot counting phase (such as requirements that voters who lack a particular form of ID cast provisional ballots and then cure those ballots through an onerous process) can be challenged under section 2 regardless of their effect on turnout itself. ${ }^{50}$

Just as fundamentally, section 2 forbids the use of practices that result "in a denial or abridgment of the right . . . to vote on account of race" or languageminority status. ${ }^{51}$ A longstanding canon of statutory construction directs courts to "avoid[] interpreting statutes in a way that "renders some words altogether redundant." 52 Accordingly, there are situations in which jurisdictions can potentially abridge the right to vote even if they do not deny it altogether. There is a rich scholarly debate over the meaning of abridgment. Michael Morley has written that in considering what abridgement meant for purposes of the Reduction of Representation Clause of the Fourteenth Amendment, there was consensus that it "referred to the imposition of qualifications to vote for blacks, such as property or intelligence requirements, that did not also apply to white people," while a qualification "that applied to persons of all

${ }^{48}$ Harris v. Graddick, 593 F. Supp. 128, 135 (M.D. Ala. 1984); see also Obama for Am. v. Husted, 697 F.3d 423, 436 (6th Cir. 2012) ("A restriction on the fundamental right to vote...constitutes irreparable injury."); Order Granting Plaintiff's Motion for Preliminary Injunction at 23-24, Brakebill v. Jaeger, Case No. 1:16-cv-008 (D.N.D. Aug. 1, 2016), ECF No. 50 [hereinafter Brakebill Order] (finding that the plaintiffs would suffer an irreparable injury if enforcement of North Dakota's strict voter ID law were to prevent them from voting in an upcoming election).

4952 U.S.C. $\$ 10310(\mathrm{c})(1)$ (emphasis added).

${ }^{50}$ Cf. Connecticut v. Teal, 457 U.S. 440, 451 (1982) (rejecting the suggestion "that disparate impact" in a Title VII case "should be measured only at the bottom line" because each individual should enjoy equal "opportunity" at every stage of the process (emphasis omitted)). Moreover, as the Fourth Circuit recently pointed out, turnout figures include voters whose ballots ultimately are not counted for failure to comply with the challenged restrictions. N.C. State Conf. of NAACP v. McCrory, 831 F.3d 204, 232 (4th Cir. 2016).

5152 U.S.C. $\$ 10301$ (a) (emphasis added). This language is drawn from the Fifteenth Amendment's declaration that "[t]he right of citizens of the United States to vote shall not be denied or abridged ... on account of race, color, or previous condition of servitude." U.S. CONST. amend. XV, $\S 1$.

${ }^{52}$ South Dakota v. Yankton Sioux Tribe, 522 U.S. 329, 347 (1998) (quoting Gustafson v. Alloyd Co., 513 U.S. 561, 574 (1995)). 
races did not 'abridge' anyone's right to vote on account of race." 53 The prohibition on abridgment, in this reading, forbids "caste legislation." 54 So it would certainly be an abridgment of the right to vote if a jurisdiction required black voters to cast their ballots in person while allowing white voters to cast absentee ballots; this would be true even if every black voter who wanted to vote was able to get to the polls. ${ }^{55}$ White citizens under that scenario would have a more capacious right to vote than would black citizens, even if every citizen had the same basic entitlement. Franita Tolson has offered a broader reading of abridgment, showing that there was vigorous congressional debate from Reconstruction through the beginning of the twentieth century over whether emerging restrictions on the franchise such as literacy tests, durational residency requirements, and poll taxes were abridgments even though none of those provisions involved facial discrimination against aspiring black voters. ${ }^{56}$

But regardless of which reading we might adopt as purely a matter of constitutional interpretation, because the central aim of the 1982 amendments to section 2 was to eliminate the Fourteenth and Fifteenth Amendment requirements that a plaintiff prove a racially discriminatory purpose, ${ }^{57}$ abridgment under section 2 can occur even when a facially neutral practice not aimed at minority voters results in minority citizens having "less" (and not "no") opportunity to participate equally. Because "the question whether the political processes are 'equally open' depends upon a searching practical evaluation" of how the challenged practice "interacts with social and historical conditions," 58 courts should consider the actual voting behavior of minority voters in making the determination whether the process is equally open. For example, in a jurisdiction where black voters disproportionately vote on Sundays - particularly when that decision can be explained as stemming from factors connected to socioeconomic disparities ${ }^{59}$ - a decision to cut back on

${ }^{53}$ Michael T. Morley, Remedial Equilibration and the Right to Vote Under Section 2 of the Fourteenth Amendment, 2015 U. CHI. LEGAL F. 279, 310 (quoting ConG. GlOBE, 39th Cong., 1st Sess. 353 (1866) (statement of Rep. Rogers)); see also John Harrison, Reconstructing the Privileges or Immunities Clause, 101 YALE L.J. 1385, 1421 (1992) (making a similar argument).

${ }^{54}$ Harrison, supra note 53, at 1422.

55 This example comes from a stylized version of the facts in Brown v. Post, 279 F. Supp. 60, 62-63 (W.D. La. 1968), one of the few section 2 vote denial cases mentioned in the 1982 Senate Report. See S. REP. No. 97-417, at 30 n.119 (1982).

${ }^{56}$ Franita Tolson, What Is Abridgment?: A Critique of Two Section Twos, 67 ALA. L. REV. 433, 467-78 (2015).

57 Thornburg v. Gingles, 478 U.S. 30, 35, 43 (1986).

58 Id. at 45, 47 (quoting S. REP. NO. 97-417, at 30).

${ }^{59}$ For example, minority voters who do not own cars may find voting on Sundays easier because their church will provide transportation to the polls; minority voters with limited literacy or English proficiency may find voting on Sundays easier because trusted relatives or friends who work during the week are better able to provide assistance; and minority voters who work multiple jobs or whose jobs are located far from where they live may find voting on Sundays easier because it does not force them to sacrifice needed income in order to vote. For discussions of Sunday voting, see North Carolina State 
Sunday voting will, as a practical matter, disproportionately burden or abridge black citizens' right to vote. ${ }^{60}$ In short, even if a voter ultimately makes it to the polls, her right to vote may have been abridged if she gets there only after overcoming new or different burdens. ${ }^{61}$ Abridgment of the right to vote occurs when a practice either forecloses or "substantially interferes" with a citizen's ability to cast a ballot and have it counted. ${ }^{62}$

Finally, as a practical matter, determining whether a challenged practice has depressed minority turnout can be extraordinarily complex. ${ }^{63}$ The underlying conceptual question is a counterfactual: absent the challenged practice that was actually in place, would the voters affected by the challenged practice have turned out? That question cannot be answered by looking at aggregate turnout figures because those figures include voters (sometimes an overwhelming percentage of the electorate) who are not affected at all by the challenged practice. ${ }^{64}$ For example, consider voter identification requirements. Even if black or Latino voters in Texas are roughly twice or thrice as likely as

Conference of NAACP v. McCrory, 831 F.3d 204, 216-17, 226 (4th Cir. 2016), and Ohio State Conference of NAACP v. Husted, 768 F.3d 524, 539 (6th Cir. 2014).

${ }^{60}$ See N.C. Conf., 831 F.3d at 236 (calling North Carolina's decision to cut back on Sunday voting "as close to a smoking gun as we are likely to see in modern times" in purposefully cutting back black "access to the franchise").

${ }^{61}$ See Stephen B. Pershing, The Voting Rights Act in the Internet Age: An Equal Access Theory for Interesting Times, 34 LOY. L.A. L. REV. 1171, 1183 (2001) (arguing that section 2 should be available to challenge voting regimes that make "voting more convenient for whites than for minority voters" even if minority voters "overcame a convenience 'handicap' that we could all agree was unjust to impose by race as a matter of principle").

${ }^{62}$ Keene v. Meese, 619 F. Supp. 1111, 1123 (E.D. Cal. 1985) (giving a similar construction to the word "abridge[]" in the First Amendment, having "been unable to uncover any generalized discussion of the meaning of the term" after canvassing a series of cases in which the Supreme Court used synonyms like "restrict," "limit," "impinge," and "burden"), rev'd on other grounds, 481 U.S. 465 (1987).

63 See THE LAW OF DEMOCRACY, supra note 1, at 125-26; see also Issacharoff, Ballot Bedlam, supra note 21, at 1381-82 (collecting and discussing studies); Nelson, supra note 16, at 580 n.2 (same); Nicholas O. Stephanopoulos, Elections and Alignment, 114 CoLUM. L. REV. 283, 328-29 (2014) (same); Tokaji, Applying Section 2, supra note 15, at 475-76 (same). For some representative examples from the rich empirical literature, see Stephen Ansolabehere \& David M. Konisky, The Introduction of Voter Registration and Its Effects on Turnout, 14 Pol. ANALysis 83, 90-97 (2006); Robert S. Erikson \& Lorraine C. Minnite, Modeling Problems in the Voter Identification-Voter Turnout Debate, 8 ELECTION L.J. 85, 85-98 (2009); Michael J. Pitts, Empirically Measuring the Impact of Photo ID over Time and Its Impact on Women, 48 IND. L. REV. 605, 605-07 (2015); and Barry C. Burden et al., The Turnout Effects of Early Voting, Election Day Registration, and Same Day Registration in the 2008 Presidential Election (Sept. 17, 2009) (unpublished manuscript), http://users.polisci.wisc.edu/apw/archives/Burden_et_al.pdf [https://perma.cc/N3TM $-\mathrm{ARVQ]}$.

${ }^{64}$ It would be totally infeasible in a challenge to a jurisdiction-wide practice to determine voter-by-voter turnout across elections. 
Anglo voters to lack the required IDs, ${ }^{65}$ it's still the case that the vast majority of minority voters $d o$ have them-more than $93 \%$ of Latino voters and nearly $95 \%$ of black voters. ${ }^{66}$ Thus, the effects of voter ID may well be largely obscured if a court looks to aggregate turnout figures. But, as the Supreme Court recently remarked in rejecting Texas's claim that its restrictive abortion law did not impose an undue burden "because the women affected by those laws are not a 'large fraction' of Texan women 'of reproductive age,", the universe is not the "relevant denominator." 67 The relevant pool is those individuals "for whom [the provision] is an actual rather than an irrelevant restriction." 68

Even more so, determining whether there have been turnout effects cannot be answered simply by looking at aggregate turnout before and after the practice was put into place. The two elections may have differed in a variety of important ways that might muddy or dwarf the effects of the practice at issue even with respect to minority voters as a group. Which candidates were on the ballot, the competitiveness of individual contests, campaign spending, get-outthe-vote efforts, changes in the composition of the electorate, even the weather can affect turnout. ${ }^{69}$ And countermobilization against voting restrictions can dampen negative turnout effects, ${ }^{70}$ but to the extent that that countermobilization demands resources, the maintenance of prior turnout levels is evidence, not disproof, of a burden. ${ }^{71}$

65 Veasey v. Abbott, 830 F.3d 216, 250-51 (5th Cir. 2016) (en banc).

${ }^{66} \mathrm{Id}$. at 251 . In some states, the number of voters affected by ID requirements is significantly higher. For example, in North Dakota, $23.5 \%$ of Native Americans currently lack valid voter ID (compared to $12 \%$ of other voters, which is still a substantial proportion). See Brakebill Order, supra note 48, at 8.

${ }^{67}$ Whole Woman's Health v. Hellerstedt, 136 S. Ct. 2292, 2320 (2016) (quoting Planned Parenthood of Se. Pa. v. Casey, 505 U.S. 833, 894-95 (1992)).

${ }^{68} \mathrm{Id}$. (alteration in original) (quoting Planned Parenthood of Se. Pa., 505 U.S. at 894-95). In a work in progress, I explore this connection in greater depth. Pamela S. Karlan, Undue Burdens in Abortion and Voting Cases (unpublished manuscript) (on file with author).

${ }^{69}$ See N.C. State Conf. of NAACP v. McCrory, 831 F.3d 204, 232 (4th Cir. 2016) (discussing some of these factors); $c f$. STEVEn F. LAwson, Black Ballots: Voting RiGHTS IN THE SOUTH, 1944-1969, at 423 n.117 (1976) (explaining that the Voting Rights Act's preclearance coverage formula swept in some jurisdictions in the North where there was no evidence of racial discrimination because turnout was depressed by cold weather on Election Day 1964).

${ }^{70}$ See Barry C. Burden et al., Election Laws, Mobilization, and Turnout: The Unanticipated Consequences of Election Reform, 58 AM. J. POL. SCI. 95, 97-99 (2014) (discussing mobilization and cutbacks to early voting); Jack Citrin et al., The Effects of Voter ID Notification on Voter Turnout: Results from a Large-Scale Field Experiment, 13 ELECTION L.J. 228, 235 (2014) (suggesting that the awareness of a voter ID requirement can sometimes boost turnout).

${ }^{71}$ See Nelson, supra note 16, at 583 (“"T] he backlash effect does not negate the increased burden placed on minorities' right to vote even if, ultimately and intermittently, minority voters can bear it and elect candidates of their choice."). 
Nonetheless, although turnout effects are not a necessary precondition of a vote denial claim under section 2's results test, they do play a crucial role if a plaintiff challenges a particular restriction on an intent theory (which is also available under section 2). ${ }^{72}$

There are two very different sorts of racially discriminatory purposes that might support finding intent liability under section 2 . First, the challenged law might have been adopted or maintained because of racial animus - a belief that members of the minority group do not deserve the right to participate in the governmental process because they are in some way inferior to the majority. ${ }^{73}$ This animus can (but need not) be entirely outcome-independent. Actual or predicted turnout effects would be irrelevant to this sort of discriminatory purpose claim.

But second, and far more likely in contemporary times, the challenged law might target minority voters for instrumental reasons: because the law's backers believe it will be to their political benefit to restrict minority voting since minority voters disproportionately support the backers' political opponents. In this world, vote denial is the product not of animus, but of an "inevitable tendency of elected officials to entrench themselves by targeting groups unlikely to vote for them."74

Instrumental discriminatory purpose of this sort almost by necessity rests on beliefs or predictions about turnout. As the Fourth Circuit recently explained in North Carolina State Conference of the NAACP v. McCrory, those beliefs in turn implicate one of the most significant Senate Report factors: racially polarized voting. ${ }^{75}$ Racial bloc voting "provide[s] an incentive for [racial] discrimination in the regulation of elections." "76 And when race is a particularly good predictor of partisanship - indeed, in North Carolina, one of the defense experts conceded that being black was "a better predictor for

72 The Senate Report makes clear that either proof of discriminatory intent or proof of a discriminatory result suffices to establish section 2 liability. See S. REP. No. 97-417, at 27 (1982).

73 To the extent that offender-disenfranchisement laws rest on beliefs about the moral worth of offenders and their right to be considered part of the political community, these laws might be characterized as animus-based. See Pamela S. Karlan, Convictions and Doubts: Retribution, Representation, and the Debate over Felon Disenfranchisement, 56 STAN. L. REV. 1147, 1155, 1166 (2004) (suggesting the ways in which this view captures contemporary reality). See generally Note, The Disenfranchisement of Ex-Felons: Citizenship, Criminality, and "The Purity of the Ballot Box," 102 HARV. L. REV. 1300 (1989) (same). I am not suggesting here that any animus is invariably race based, although sometimes offender disenfranchisement statutes are in fact the product of purposeful racial discrimination. See, e.g., Hunter v. Underwood, 471 U.S. 222, 228-30 (1985); McLaughlin v. City of Canton, 947 F. Supp. 954, 976-78 (S.D. Miss. 1995).

${ }^{74}$ N.C. Conf., 831 F.3d at 214.

${ }^{75}$ Id.; see also S. REP. No. 97-417, at 29 (the second numbered Senate Report factor). Gingles made racially polarized voting the sine qua non of vote dilution cases. See Thornburg v. Gingles, 478 U.S. 30, 47-50 (1986). For a discussion of the centrality of racial bloc voting, see generally Issacharoff, Polarized Voting, supra note 15.

${ }^{76}$ N.C. Conf., 831 F.3d at 222. 
voting Democratic than party registration" 77 - then targeting minority voters is an especially effective way for the party in power to skew turnout in its direction. In many parts of the United States today, that means that Republican elected officials have an incentive to restrict the voting practices and procedures most likely to be used by minority voters and to impose burdens that are likely to disproportionately prevent minority voters from casting a ballot and having it counted.

Even in these instrumental discriminatory intent cases, however, plaintiffs should not be required to prove actual turnout effects. The question here is not whether the framers of the challenged law are correct that it will depress turnout. Indeed, the more blatant their racial targeting, the more likely there may be countermobilization that at least in the short run counteracts turnout effects. ${ }^{78}$ Rather, the relevant inquiry asks whether actors who adopted the challenged practice targeted minority voters at least in part to skew the composition of the electorate in their favor. That is, the backers' perception of turnout effects, rather than the reality of those effects, is what matters.

\section{THE LEGAL SigNIFICANCE OF CHANGE}

While some section 2 vote denial cases have involved longstanding practices, ${ }^{79}$ most successful litigation has generally involved challenges to newly imposed restrictions. ${ }^{80}$ But in considering whether the rule before them imposes a burden, courts frequently have confronted the fact that the rule the plaintiff is seeking to reinstate is itself a relatively recent expansion of voting rights, and often it involves a practice that is unavailable in many other jurisdictions. States as otherwise diverse as Alabama, Connecticut, New York, Missouri, and Michigan, for example, offer no form of early voting (other than absentee voting for one of a limited number of qualifying reasons). ${ }^{81}$ Only thirteen states currently offer aspiring voters any opportunity for same-day

\footnotetext{
${ }^{77}$ Id. at 225 (emphasis added).

78 See sources cited supra note 70 (discussing the evidence of countermobilization); see also Issacharoff, Ballot Bedlam, supra note 21, at 1385 (describing how some restrictions may actually backfire).

${ }^{79}$ The largest category of challenges to longstanding practices involves a series of ultimately unsuccessful challenges to offender disenfranchisement statutes. See Tokaji, New Vote Denial, supra note 16, at 700-01, 714-18 (discussing this litigation).

${ }^{80}$ The North Carolina, Texas, Ohio, and Wisconsin cases all fall into this category. See generally N.C. Conf., 831 F.3d 204; Veasey v. Abbott, 830 F.3d 216 (5th Cir. 2016) (en banc); Ohio State Conf. of NAACP v. Husted, 768 F.3d 524 (6th Cir. 2014); Frank v. Walker, 17 F. Supp. 3d 837 (E.D. Wis. 2014).

${ }^{81}$ See Absentee and Early Voting, NAT'L CONF. ST. Legislatures (May 26, 2016), http://www.ncsl.org/research/elections-and-campaigns/absentee-and-early-voting.aspx [https://perma.cc/V74M-Y24D].
} 
voter registration. ${ }^{82}$ So how can courts conclude that the reduction or elimination of these opportunities in a state that previously offered them imposes an impermissible burden under section 2?

A fundamental starting point for answering that question lies in recognizing that the Voting Rights Act as a whole is not neutral with respect to expansions and contractions of the right to vote. Rather, it expresses a clear congressional purpose to expand opportunities to participate. This can be seen in key substantive provisions that outlaw literacy tests ${ }^{83}$ and poll taxes ${ }^{84}$ - two of the primary restrictions on the ability of citizens to register and cast a ballot that existed at the time of the Act's initial passage. Similarly, by instituting a results test, section 2 can be used to force jurisdictions to abandon practices that do not provide minority citizens with an equal opportunity to participate in the political process even if those practices would pass constitutional muster.

The Congresses that enacted and amended the Voting Rights Act were explicitly concerned that American history revealed a cycle in which voting gains by minority citizens had been subjected to retrenchment. ${ }^{85}$ The Act's most direct response to this concern was, of course, the preclearance regime of section 5. To be sure, in Shelby County v. Holder, the Supreme Court identified two aspects of that regime that caused the Court serious constitutional concern: the requirement that covered jurisdictions "obtain federal permission before enacting any law related to voting - a drastic departure from basic principles of federalism"-and the selective imposition of preclearance on only a limited class of states - a "dramatic departure from the principle that all States enjoy equal sovereignty." 86 But nothing in Shelby

${ }^{82}$ See Same Day Voter Registration, NAT'L CONF. ST. LEGISLATURES (Aug. 25, 2016), http://www.ncsl.org/research/elections-and-campaigns/same-day-registration.aspx [https://perma.cc/H3C7-UR8N].

8352 U.S.C. $§ 10501$ (b) (Supp. II 2014) (providing that no citizen can be denied the right to vote based on "any requirement that a person as a prerequisite for voting or registration for voting (1) demonstrate the ability to read, write, understand, or interpret any matter, [or] (2) demonstrate any educational achievement or his knowledge of any particular subject").

${ }^{84} I d$. $\S 10306$ (a) (“" $[\mathrm{T}]$ he requirement of the payment of a poll tax as a precondition to voting (i) precludes persons of limited means from voting or imposes unreasonable financial hardship upon such persons as a precondition to their exercise of the franchise, (ii) does not bear a reasonable relationship to any legitimate State interest in the conduct of elections, and (iii) in some areas has the purpose or effect of denying persons the right to vote because of race or color. ... [T] he constitutional right of citizens to vote is denied or abridged in some areas by the requirement of the payment of a poll tax as a precondition to voting.").

85 See Brian K. LANDSberg, Free at Last to Vote: The Alabama Origins of the 1965 Voting RightS ACT 84-170 (2007) (describing the "well-established pattern of protean voting laws" to which the 1965 Voting Rights Act was a congressional response). For the leading account of this cyclical history, see generally ALEXANDER KEYSSAR, THE Right To Vote: The CONTESTEd History OF DEMOCRACY IN THE United STATES (2000).

${ }^{86}$ Shelby Cty. v. Holder, 133 S. Ct. 2612, 2618 (2013). 
County casts doubt on the authority of Congress to protect voting rights from being cut back through more conventional means. ${ }^{87}$

Expansions and cutbacks to voting opportunities are not similarly situated within a totality of the circumstances approach. ${ }^{88}$ Existing legal regulations have shaped voters' and other political actors' expectations and behavior. ${ }^{89}$ Citizens decide whether or not to vote (as they decide so much else in their

${ }^{87}$ Indeed, only a week earlier, in Arizona v. Inter Tribal Council of Arizona, Inc., 133 S. Ct. 2247 (2013), the Court had reiterated that Congress's power "over the 'Times, Places and Manner' of congressional elections 'is paramount, and may be exercised at any time, and to any extent which it deems expedient; and so far as it is exercised, and no farther, the regulations effected supersede those of the State which are inconsistent therewith." 'Id. at 2253-54 (first quoting U.S. CoNST. art. I, § 4; and then quoting Ex parte Siebold, 100 U.S. 371, 392 (1880)). Congress can leverage its Elections Clause power in Article I, Section 4 "to provide a complete code for congressional elections, not only as to times and places, but in relation to notices, registration, supervision of voting, protection of voters, prevention of fraud and corrupt practices, counting of votes, duties of inspectors and canvassers, and making and publication of election returns." Smiley v. Holm, 285 U.S. 355, 366 (1932); cf. Cook v. Gralike, 531 U.S. 510, 523-24 (2001) (reiterating this breadth). Although as a formal matter, the Elections Clause power involves congressional elections, as a practical matter Congress can leverage this power to cover all elections because states are loathe to run two separate elections processes. See, e.g., Daniel P. Tokaji, Intent and Its Alternatives: Defending the New Voting Rights Act, 58 ALA. L. REV. 349, 367 (2006) (pointing out that states have been reluctant to do so in the past when Congress has used its Elections Clause power to regulate aspects of voter registration).

88 See League of Women Voters of N.C. v. North Carolina, 769 F.3d 224, 241-42 (4th Cir. 2014) ("The fact that a practice or law eliminates voting opportunities that used to exist under prior law that African Americans disproportionately used is therefore relevant to an assessment of whether, under the current system, African Americans have an equal opportunity to participate in the political process as compared to other voters." (quoting Ohio State Conf. of NAACP v. Husted, 768 F.3d 524, 558 (6th Cir. 2014))).

As Janai Nelson explains, the right to vote (as opposed to the right to elect the candidate of one's choice that is at issue in vote dilution cases) does not involve a zero-sum game: Votes "do not involve the allocation of a limited resource; rather, the right to vote can be extended to countless individuals without denying others access to that right." Nelson, supra note 16, at 611. While extending the right to vote to noncitizens might properly be viewed as adversely affecting citizens' right to vote, see Brown v. Bd. of Comm'rs, 722 F. Supp. 380, 399 n.24 (E.D. Tenn. 1989) (striking down a city ordinance that allowed nonresidents who owned even a trivial amount of property in the city to vote in municipal elections on the grounds that "the law currently would permit Muammar elQaddafi to buy a parcel of land in Chattanooga and deed it to thousands of Libyans who would then be able to control the outcome of Chattanooga's elections"), there is no warrant for finding that expanding the right to vote of eligible citizens imposes a cognizable harm on other voters.

${ }^{89}$ Cf. Obama for Am. v. Husted, 697 F.3d 423, 442 (6th Cir. 2012) (stating that changes to "voting provisions that have been in effect since 2005 and have been relied on by substantial numbers of voters for the exercise of their franchise are properly considered as a burden" under the Fourteenth Amendment standard and that "[t]o conclude otherwise is to ignore reality"). 
lives) based on the costs and benefits from casting a ballot. ${ }^{90}$ When the cost of voting goes down - for example, because early voting consumes less of an individual's time by shortening voting lines or making it easier to get to the polls or because same-day registration enables an aspiring participant to combine two tasks into a single visit to the board of elections ${ }^{91}$ - some individuals who did not participate previously will enter the system and begin to vote. Particularly in jurisdictions where minority voters are disproportionately likely to lack various politically salient resources ranging from money to flexibility with respect to their time to basic and civic literacy, ${ }^{92}$ providing minority voters with an equal opportunity to participate depends on maintaining voting as a low cost activity. ${ }^{93}$ Conversely, when the costs of voting go up-for example, because a citizen currently lacks a conforming ID and therefore has to spend time acquiring the underlying documentation before traveling to a government office to obtain (even a nominally free) $\mathrm{ID}^{94}$ or because the government adopts new rules that lead to longer lines in polling places ${ }^{95}$ - some individuals will conclude that the cost

${ }^{90}$ The canonical source for this common-sense insight is ANTHONY DOWNS, AN ECONOMIC THEORY OF DEMOCRACY (1957).

${ }^{91}$ See id. at 265 (arguing that "time is the principal cost of voting").

92 See Veasey v. Perry, 71 F. Supp. 3d 627, 664 (S.D. Tex. 2014) (discussing these difficulties), aff'd in relevant part and vacated in part sub nom. Veasey v. Abbott, 830 F.3d 216 (5th Cir. 2016) (en banc); see also Brakebill Order, supra note 48, at 9-10 (explaining that "obtaining a qualifying voter ID is much easier to accomplish for people who live in urban areas, have a good income, are computer-literate, have a computer and printer, have a good car and gas money, have a flexible schedule, and understand how to navigate the state's administrative procedures," than it is for Native Americans living in rural areas or on reservations).

93 See N.C. State Conf. of NAACP v. McCrory, 831 F.3d 204, 233 (4th Cir. 2016) ("[S]ocioeconomic disparities establish that no mere 'preference' led African American[] [voters in North Carolina] to disproportionately use early voting, same-day registration, out-of-precinct voting, and preregistration.").

${ }^{94}$ See, e.g., Frank v. Walker, Case No. 11-C-1128, 2016 WL 3948068, at *10-14 (E.D. Wis. July 19, 2016) (discussing some of the burdens in one such process).

95 See, e.g., Mich. State A. Philip Randolph Inst. v. Johnson, 833 F.3d 656, 663-64 (6th Cir. 2016) (emphasizing that the elimination of straight-ticket voting in Michigan might increasing waiting times, particularly in heavily African-American communities which have "historically faced some of the longest wait times in the state" and that "[l]onger lines at the polls 'reduce[] the confidence voters have that their votes are counted,' impose additional monetary costs on voters that must stand in line, and may even turn some voters away from voting at all" (second alteration in original) (quoting CHARLES Stewart III, Caltech/Mit Voting Tech. Project, Managing Polling Place RESOURCES 11-12 (2015))). For discussions of long lines and voting opportunities, see, for example, Rabia Belt, Contemporary Voting Rights Controversies Through the Lens of Disability, 68 STAN. L. REV. 1491, 1508 (2016) (discussing how long lines can both "add to the "time tax" that voting imposes on many voters and may make voting impossible for individuals with some disabilities); Justin Levitt, "Fixing That": Lines at the Polling Place, 28 J.L. \& PoL. 465, 468 n.22 (2013) (summarizing studies showing that minority voters faced longer lines than nonminority voters and that a higher proportion of African- 
is too high, and will cease voting. An African-American witness at the Texas voter ID trial put the point starkly. She had to pay $\$ 42$ to obtain her Mississippi birth certificate (a necessary underlying document to get the nominally free Texas voter identification document). She had not yet done so because she lived on \$321 a month and explained:

[W]hen you're getting a certain amount of money, you're going to put the money where you feel the need is most urgent at the time ... I had to put the $\$ 42.00$ where it was doing the most good. It was feeding my family, because we couldn't eat the birth certificate... [a]nd we couldn't pay rent with the birth certificate, so, [I] just wrote it off. ${ }^{96}$

It blinks common sense (and common humanity in a case like Mrs. Bates's) to say that a law that raises the cost of voting imposes no burden. The real question cannot be the existence of $a$ burden; rather, it is the magnitude of and justification for the burden and, for purposes of section 2, the presence of a racially disparate impact caused by or linked to the effects of past or contemporary discrimination.

Giving legal significance to the fact that the challenged practice involves a restrictive change is not the equivalent of smuggling section 5's retrogression standard into section 2's results test. Section 5 is directed solely at "backsliding" 97 and compares minority citizens' political position under the prior, benchmark regime to their position under the new regime. If they are worse off, that is the end of the liability inquiry: the change will not be precleared. By contrast, in a section 2 case, comparison of the costs of voting in the prior and in the challenged regime can inform the decision whether there is a burden. ${ }^{98}$ But the question whether that burden is discriminatory requires comparing the position of minority voters today not to minority voters' prior position, but rather to the present position of white voters.

Finally, although it cannot be dispositive, the fact that a jurisdiction has until recently used a system that imposes fewer costs on voters provides at least preliminary evidence that a less burdensome system is feasible and tolerably serves the state's legitimate interests. ${ }^{99}$ In elaborating on the final

American voters than non-African-American voters cited long lines as a factor in their not voting); and Charles Stewart III, Waiting to Vote in 2012, 28 J.L. \& POL. 439, 458 (2013) (finding that precincts that are heavily nonwhite are more likely to face long lines).

96 Veasey v. Perry, 71 F. Supp. 3d at 665 (alterations in original) (quoting witness Sammie Bates, Pls.' Ex. 1090, at 14-17).

${ }^{97}$ Reno v. Bossier Parish Sch. Bd., 528 U.S. 320, 335 (2000).

${ }^{98}$ League of Women Voters of N.C. v. North Carolina, 769 F.3d 224, 241 (4th Cir. 2014).

${ }^{99}$ See N.C. State Conf. of NAACP v. McCrory, 831 F.3d 204, 237 (4th Cir. 2016) (observing that North Carolina's State Board of Elections considered same-day registration to have been "a success" (quoting a report by the North Carolina State Board of Elections)); Brakebill Order, supra note 48, at 26 (observing that requiring the state to return to its prior regime was "practical" because it did not involve "reinvent[ing] the 
typical factor under the totality of the circumstances approach-which asks whether "the policy underlying" the use of a particular practice "is tenuous"100 - the Senate Report squarely states that "[i]f the procedure markedly departs from past practices ... that bears on the fairness of its impact." 101 If a state has allowed its citizens to vote either without providing proof of identity at all or upon providing any one of a wide range of documents, this suggests that a decision to restrict the right to vote to individuals possessing only a small handful of documents should rest on some demonstrable change of circumstances that provide a legitimate basis for cutting back on citizens' ability to exercise a fundamental right. ${ }^{102}$ Similarly, if a jurisdiction has successfully run an extended early voting period or same day registration regime, this fact will tend to undercut arguments that the burdens a more restrictive system imposes on minority voters are the unavoidable cost of pursuing the jurisdiction's other permissible goals. In light of the long history of changes in election law that have disadvantaged minority citizens, ${ }^{103}$ it is entirely appropriate for courts faced with a law that imposes new costs to ask whether a jurisdiction has a meritorious justification for making the change and to be skeptical that restrictions that disproportionately affect minority voters can survive scrutiny under section $2 .{ }^{104}$

wheel"); see also Tokaji, Applying Section 2, supra note 15, at 478 ("Where a state goes from a more permissive voting rule to a stricter one, plaintiffs will naturally be in a better position to show that the disparate impact could be avoided by a different practice: namely, by introducing evidence on the effect of the practice in effect beforehand.").

100 S. REP. NO. 97-417, at 29 (1982).

${ }^{101}$ Id. at 29 n. 117 .

102 See, e.g., Brakebill Order, supra note 48, at 22 (observing, in the course of granting a preliminary injunction against North Dakota's imposition of a new voter ID requirement that eliminated the prior "fail-safe" provisions that enabled voters without the required ID to cast ballots that would be counted, that the state had "failed to present any evidence showing that [the eliminated protections had] ... resulted in voter fraud in the past, or are particularly susceptible to voter fraud in the future"). I explain below why a change in party control of a legislature and a desire to reduce votes for one's political opponents cannot be such a change. See infra text accompanying notes 120-32.

${ }^{103}$ For discussions of this history, see generally KEYSSAR, supra note 85, and KOUSSER, supra note 44.

${ }^{104}$ In recent years, the Supreme Court has imposed a "Purcell principle"-so named after Purcell v. Gonzalez, 549 U.S. 1 (2006) (per curiam) — "that courts should not issue orders which change election rules in the period just before the election." Richard L. Hasen, Reining in the Purcell Principle, 43 FLA. ST. U. L. REV. 427, 428 (2016). The central idea behind the Purcell principle is that last-minute changes sow voter confusion. There is nothing unique about judicial, as opposed to legislative or administrative, changes when it comes to voter confusion. To be sure, Shelby County means that the automatic "freezing principle" of section 5 is no longer in place. See LANDSBERG, supra note 85, at 84-105 (discussing how section 5 was designed to freeze existing practices into place). But courts faced with a section 2 challenge to a newly enacted restriction should be entitled to take into account the fact that the change was made at a time when it was impossible to fully adjudicate its legality before an impending election. 


\section{TENUOUSNESS AND TOTALITY}

The two elements of the emerging framework bear a complicated relationship to the factors that have traditionally guided a section 2 results inquiry. Although the Sixth Circuit's shorthand version of the first elementthat because of the challenged practice minority citizens "will have a harder time voting than other members of the electorate"105_suggests that the first element is straightforwardly satisfied by showing a disparate impact, the more formal articulation of the element literally equates the phrase "discriminatory burden" with the statutory language in section 2 that describes the ultimate conclusion of a totality of the circumstances inquiry rather than its inputs. ${ }^{106}$ Akin to the way that the second and third prongs of the Gingles test foregrounded and elaborated upon one of the Senate Report factors (there, the extent to which voting was "racially polarized" 107 ), the second element of the emerging framework is drawn from one of the Senate Report factors: here, the "extent to which members of the minority group in the state or political subdivision bear the effects of discrimination in such areas as education, employment and health, which hinder their ability to participate effectively in the political process." 108 What the second element adds is a requirement that plaintiffs provide a causal connection, showing how the disproportionate difficulty in voting the challenged practice imposes on minority citizens (that is, the "discriminatory burden") is at least in part "caused by or linked to 'social and historical conditions' that have or currently produce discrimination against members of the protected class." 109 That causal connection

105 Ohio State Conf. of NAACP v. Husted, 768 F.3d 524, 555 (6th Cir. 2014).

106 Compare League of Women Voters of N.C. v. North Carolina, 769 F.3d 224, 240 (4th Cir. 2014) ("[T]he challenged 'standard, practice, or procedure' must impose a discriminatory burden on members of a protected class, meaning that members of the protected class 'have less opportunity than other members of the electorate to participate in the political process and to elect representatives of their choice." (quoting Ohio State Conf., 768 F.3d at 553-54)), and Veasey v. Abbott, 830 F.3d 216, 244 (5th Cir. 2016) (en banc) (quoting League of Women Voters, 769 F.3d at 240), with 52 U.S.C. § 10301(b) (Supp. II 2014) (stating that a violation of the results test "is established if, based on the totality of circumstances, it is shown that the political processes leading to nomination or election in the State or political subdivision are not equally open to participation by members of a [protected] class of citizens ... in that its members have less opportunity than other members of the electorate to participate in the political process and to elect representatives of their choice").

107 Compare Thornburg v. Gingles, 478 U.S. 30, 50-51 (1986) ("Second, the minority group must be able to show that it is politically cohesive. . . Third, the minority must be able to demonstrate that the white majority votes sufficiently as a bloc to enable it . . usually to defeat the minority's preferred candidate."), with S. REP. NO. 97-417, at 29 (1982) (second factor).

108 S. REP. No. 97-417, at 29 (fifth factor).

109 Ohio State Conf., 768 F.3d at 554 (quoting Gingles, 478 U.S. at 47). The Senate Report, by contrast, does not seem to require that proof of causation: 
requirement makes sense, since unless the burden can be tied in some way to the challenged practice, it is hard to see how striking the practice down will provide more equal voting opportunities. ${ }^{110}$ It can also be satisfied straightforwardly by showing, for example, that the reason African-American voters disproportionately used an eliminated same-day registration opportunity was that they are disproportionately poor and therefore both move more often (thus being required to reregister) and both lack access to automobiles and have work schedules that make it harder for them to make two trips-one to register and one to vote. The vote denial jurisprudence then, accords special weight to consideration of how current socioeconomic disparities that are the product of prior (and contemporary) discrimination make it harder for minority citizens to cast ballots and have those ballots counted, similar to the way that vote dilution cases have turned to a significant degree on whether elections are racially polarized.

That is not to say that racially polarized voting is irrelevant to vote denial cases. As I have already explained, racial bloc voting creates an incentive for politicians who receive little support from the minority community to adopt rules that will keep minority voters from turning them out of office. 111 Moreover, racial bloc voting means that officials whose electoral success does not depend on minority voters' support can ignore distinctive minority group interests that "are capable of aid or amelioration by government." 112 In particular, they can ignore minority citizens' interest in election rules that expand access to the political process.

Beyond socioeconomic disparities that interact with costly voting procedures to render minority citizens less able to cast ballots and have them

The courts have recognized that disproportionate educational employment, income level and living conditions arising from past discrimination tend to depress minority political participation. Where these conditions are shown, and where the level, of black participation in politics is depressed, plaintiffs need not prove any further causal nexus between their disparate socio-economic status and the depressed level of political participation.

S. REP. NO. 97-417, at 29 n.114 (citation omitted).

${ }^{110} \mathrm{Cf}$. Gingles, 478 U.S. at $50 \mathrm{n} .17$ (explaining that the first Gingles factor reflects the fact that " $[\mathrm{u}]$ nless minority voters possess the potential to elect representatives in the absence of the challenged structure or practice, they cannot claim to have been injured by that structure or practice").

${ }^{111}$ See supra text accompanying notes 74-76; see also League of United Latin Am. Citizens v. Perry, 548 U.S. 399, 438-40 (2006) (describing how the Republican-controlled Texas legislature redrew a congressional district that was about to have an effective Latino voting majority to prevent Latinos from unseating an incumbent Republican member of Congress).

112 Gingles v. Edmisten, 590 F. Supp. 345, 354-55 (E.D.N.C. 1984) (three-judge court) (citing S. REP. No. 97-417, at 29) (elaborating upon the eighth Senate Report factor- "a significant lack of responsiveness on the part of elected officials to the particularized needs of the members of the minority group"), aff'd in relevant part sub nom. Thornburg v. Gingles, 478 U.S. 30 (1986). 
counted, the most salient Senate Report factor in vote denial cases is the final one: "whether the policy underlying the state or political subdivision's use of such voting qualification, prerequisite to voting, or standard, practice or procedure is tenuous." 113 Nearly all voting practices impose some costs, but an election cannot be run without rules at all. In the constitutional context, the Supreme Court has long differentiated between, on the one hand, "evenhanded restrictions that protect the integrity and reliability of the electoral process itself," 114 which are presumptively constitutional, and, on the other hand, rules that either impose a "severe" burden which can be justified only by "a state interest of compelling importance"115 or are constitutionally "invidious" because "they are unrelated to voter qualifications." 116

One thing that the Voting Rights Act adds to this balancing is a gloss on what constitutes evenhandedness. Under section 2, a voting restriction that results in minority voters having less opportunity than other citizens to participate in the political process is not "evenhanded"; it is discriminatory. Judge Lynn Adelman found in a challenge to the Wisconsin voter ID law that "photo ID laws undermine confidence in the electoral process . . . by causing members of the public to think that the photo ID requirement is itself disenfranchising voters and making it harder for citizens to vote, thus making results of elections less reflective of the will of the people."117 A Seventh Circuit panel rejected that finding with respect to constitutional claims because it saw the Supreme Court's decision upholding Indiana's photo ID law as making a finding of "legislative fact" that photo ID requirements promote public confidence. ${ }^{118}$ But with respect to section 2, we have an actual legislature - the United States Congress - expressing a lack of confidence in an election process in which minority citizens are disproportionately burdened.

"[R]acial discrimination is not just another competing consideration." 119 At the very least, unless a court concludes that the restriction actually protects the integrity and reliability of the electoral process, a restriction that imposes a discriminatory burden violates the results test of section 2. Put another way, section 2 does not permit speculative rationalizations for a challenged restriction to outweigh actual proof that the challenged practice deprives

113 S. REP. NO. 97-417, at 29.

${ }^{114}$ Crawford v. Marion Cty. Election Bd., 553 U.S. 181, 189-90 (2008) (opinion of Stevens, J.) (plurality opinion) (quoting Anderson v. Celebrezze, 460 U.S. 780, 788 n.9 (1983)).

115 Norman v. Reed, 502 U.S. 279, 289 (1992).

116 Crawford, 553 U.S. at 189 (opinion of Stevens, J.).

${ }^{117}$ Frank v. Walker, 17 F. Supp. 3d 837, 852 (E.D. Wis.), rev'd, 768 F.3d 744 (7th Cir. 2014).

${ }^{118}$ Frank v. Walker, 768 F.3d 744, 750 (7th Cir. 2014). My colleague Nate Persily has found that voters' confidence in the system does not seem to depend on whether their jurisdiction has an ID requirement. See Stephen Ansolabehere \& Nathaniel Persily, Vote Fraud in the Eye of the Beholder: The Role of Public Opinion in the Challenge to Voter Identification Requirements, 121 HARV. L. REV. 1737, 1754-59 (2008).

119 Vill. of Arlington Heights v. Metro. Hous. Dev. Corp., 429 U.S. 252, 265 (1977). 
minority citizens of an equal opportunity to participate. The section 2 totality of the circumstances test is not, when it comes to tenuousness, synonymous with standard rationality review in which a law should be upheld if there is any rational, even hypothetical, connection between the challenged practice and some legitimate government interest. ${ }^{120} \mathrm{~A}$ weak actual fit between the law and the ostensible policy behind it establishes tenuousness. ${ }^{121}$

Much of the new vote denial, as I have already explained, is the product of partisan manipulation of election rules. ${ }^{122}$ A policy of pursuing partisan advantage through restricting the right to vote should be held tenuous as a matter of law and should create a strong presumption that a plaintiff who has satisfied the two elements of the emerging framework has established a violation of section $2 .{ }^{123}$

The Supreme Court long ago held that " [f]encing out' from the franchise a sector of the population because of the way they may vote is constitutionally impermissible." 124 The Court announced that principle in the context of cases where the defendants were prepared to articulate on the record an argument for why the individuals who were being excluded were not (or were not yet) full members of the political community. ${ }^{125}$ In the new vote denial cases, no jurisdiction has argued that voting restrictions can be imposed on voters for partisan reasons. But if it is a violation of ordinary public employees' First

120 See Pamela S. Karlan, Old Reasons, New Reasons, No Reasons, 27 GA. ST. U. L. REV. 873, 874 (2011) (discussing "just how forgiving rationality review can be"). As Josh Douglas points out, in constitutional cases involving challenges to election laws, the courts have been quite deferential to proffered state justifications, often declining to go behind them to determine the actual policy being pursued. Joshua A. Douglas, (Mis)trusting States to Run Elections, 92 WASH. U. L. REV. 553, 557-58 (2015).

${ }^{121}$ See Nelson, supra note 16 , at 630 (" $[\mathrm{T}] \mathrm{o}$ the extent that the state burdens the right to vote beyond what is necessary to achieve the race-neutral policy goal, the policy is tenuous."); Pershing, supra note 61, at 1202-03 ("The more severe the disparate racial impact of procedures that have weak nonracial justifications, the more likely a court should be able to find a section 2 violation.").

122 See supra text accompanying notes 22, 78. For discussion of this point, see also Douglas, supra note 120, at 555-56; Edward B. Foley, The Separation of Electoral Powers, 74 MonT. L. REV. 139, 141 (2013); and Issacharoff, Ballot Bedlam, supra note 21, at 1370 (" $[\mathrm{T}]$ he single predictor necessary to determine whether a state will impose voteraccess restrictions is whether Republicans control the ballot-access process.").

${ }^{123}$ Dan Tokaji has recently suggested that once a plaintiff has satisfied the two elements of the emerging test, courts should require a jurisdiction "to show by clear and convincing evidence that the challenged practice's benefits outweigh its harms to voters" and that at this stage "partisan motivations should not be allowed to justify voting burdens given the correlation between race and party." Tokaji, Applying Section 2, supra note 15, at 441-42. I would actually go further. Not only can partisan motivations not justify restrictions, they should in fact count as evidence that the restrictions violate the results test.

${ }^{124}$ Carrington v. Rash, 380 U.S. 89, 94 (1965); see also Dunn v. Blumstein, 405 U.S. 330, 355 (1972).

125 See, e.g., Blumstein, 405 U.S. at 354-55; Rash, 380 U.S. at 94-96. 
Amendment rights for them to be adversely affected in their employment because of their affiliation with a political party-and it is ${ }^{126}$ - how much greater a First Amendment violation it is for ordinary citizens to be burdened in their exercise of the right to vote because of political affiliation. While some degree of partisanship is an inevitable, and acceptable, feature of the practices challenged in many vote dilution cases ("All Districting Is "Gerrymandering"" 127 ), it is entirely illegitimate in the context of vote denial. In this arena, partisan symmetry has no place; "[w]hen a legislature dominated by one party has dismantled barriers to African American access to the franchise, even if done to gain votes, 'politics as usual' does not allow a legislature dominated by the other party to re-erect those barriers."128

${ }^{126}$ See, e.g., Rutan v. Republican Party of Ill., 497 U.S. 62, 65 (1990).

${ }^{127}$ RoberT G. DiXon, JR., DEMOCRATIC REPRESENTATION 462 (1968). This is why the Supreme Court has found partisan gerrymandering cases so difficult. See generally Samuel Issacharoff \& Pamela S. Karlan, Where to Draw the Line?: Judicial Review of Political Gerrymanders, 153 U. PA. L. REV. 541 (2004). And also why the Court has treated race and politics as alternative explanations for district lines in the Shaw cases. See Easley v. Cromartie, 532 U.S. 234, 241-42 (2001).

${ }^{128}$ N.C. State Conf. of NAACP v. McCrory, 831 F.3d 204, 226 (4th Cir. 2016). As I have explained earlier, supra note 88 , expansions of the franchise to constitutionally eligible citizens cannot, in themselves, impair any constitutional right of other citizens. In Katzenbach v. Morgan, 384 U.S. 641 (1966), the Supreme Court rejected a claim by New York voters who satisfied the state's literacy requirement that section 4(e) of the Voting Rights Act (now codified at 52 U.S.C. $§ 10303(\mathrm{e})$ ), which permitted citizens educated in Puerto Rican schools to vote notwithstanding their inability to read English that their right to vote had been diluted. See Morgan v. Katzenbach, 247 F. Supp. 196, 198 (D.D.C. 1965) (three-judge court) (describing the alleged injury that provided the basis for the plaintiffs' claim), rev'd, 384 U.S. 641(1966).

To be sure, if an expansion somehow impairs the integrity of the electoral process by increasing fraud, that effect would be constitutionally cognizable. $C f$. Purcell v. Gonzalez, 549 U.S. 1, 7 (2006) (per curiam) ("Voter fraud drives honest citizens out of the democratic process.... Voters who fear their legitimate votes will be outweighed by fraudulent ones will feel disenfranchised."); Roe v. Alabama, 43 F.3d 574, 580-81 (11th Cir. 1995) (finding that an Alabama state court's decision to count absentee ballots that did not comply with notarization requirements could "violat[e]" other citizens' right to vote and "have their votes properly and honestly counted," $i d$. at 580, and "dilute the votes of those voters who met the [state-law] requirements," id. at 581). But voters who seek to have an expansion struck down would bear a heavy burden, both of proving actual fraud directly tied to the expansion of the franchise and of then showing why concerns about that fraud should outweigh the voting rights of the citizens included by the challenged practice and why that fraud could not be avoided by less draconian means than repealing the expansion. Courts faced with other challenges to expansions of the right to vote have applied rationality review to the expansions, see THE LAW OF DEMOCRACY, supra note 1, at 90 , and there is no reason to expect courts to be more demanding here.

Spencer Overton has suggested that "photo-identification requirements would deter over 6700 legitimate votes for every single fraudulent vote prevented." Spencer Overton, Voter Identification, 105 MicH. L. REv. 631, 635 (2007). With anything like that ratio between legitimate votes and potentially fraudulent votes, plaintiffs challenging the repeal of a voter ID law would surely lose. 
In Crawford v. Marion County Election Board, 129 Justice Stevens's opinion announcing the judgment suggested that if partisan considerations "had provided the only justification for a photo identification requirement" being challenged as a violation of the Fourteenth Amendment's fundamental right to vote, we might assume that it "would suffer the same fate as the poll tax at issue in Harper [v. Virginia State Board of Elections]," 130 which was struck down as "invidiously discriminat[ory]."131 But, he continued, "if a nondiscriminatory law is supported by valid neutral justifications, those justifications should not be disregarded simply because partisan interests may have provided one motivation for the votes of individual legislators." 132 Whatever may be true in the context of constitutional challenges to election regulations, in the context of section 2 , a law that denies minority voters an equal opportunity to participate simply is not "nondiscriminatory." And the relevant question is not whether the challenged law can be "supported by valid neutral justifications," but whether the actual policy behind the law is tenuous. The justification must have some basis in reality and not simply in conjecture. In First Amendment cases, the Court has squarely held that once a plaintiff shows that protected conduct was " $a$ 'motivating factor"" in the challenged action, the defendant must show "by a preponderance of the evidence that it would have reached the same decision ... . even in the absence of the protected conduct." 133 A similar rule ought to apply in section 2 cases. Once plaintiffs show that political consequences were a motivation for a voting restriction, the burden should shift to the jurisdiction to show it would have adopted the restriction in the absence of any political consequences. With respect to the recent restrictions on the franchise, that is likely to prove impossible.

When race and political affiliation are as closely entwined as they are in many of the jurisdictions whose restrictive election laws have recently been

${ }^{129}$ Crawford v. Marion Cty. Election Bd., 553 U.S. 181 (2008) (plurality opinion). In the interest of full disclosure, I note that I was co-counsel for the petitioners.

${ }^{130}$ Id. at 203 (opinion of Stevens, J.).

${ }^{131}$ Id. at 189 (quoting Harper v. Va. State Bd. of Elections, 383 U.S. 663, 666 (1966)); see also Nelson, supra note 16, at 611 ("In the context of redistricting, like employment, the potential zero-sum calculation predominates, and few, if any, decisions stand alone without some consequence on other groups of voters. For example, drawing voters into one district versus another may potentially impact the electability of one group's preferred candidate versus another group's. By contrast, in a disparate vote denial context-for example, invalidating a discriminatory voter ID provision or a felon disenfranchisement law, or preventing a voter purge that yields disparate racial results based on unsubstantiated criteria - the disparate impact claim will not visit negative consequences on any racial group. Unlike in the employment context, vote denial challenges do not involve the allocation of a limited resource; rather, the right to vote can be extended to countless individuals without denying others access to that right." (footnote omitted)).

132 Crawford, 553 U.S. at 204 ) (opinion of Stevens, J.).

133 Mt. Healthy City Sch. Dist. Bd. of Educ. v. Doyle, 429 U.S. 274, 287 (1977) (emphasis added). It derived this rule from the rule announced with respect to intentional racial discrimination in Village of Arlington Heights. See id. at 287 n.2 (citing Vill. of Arlington Heights v. Metro. Hous. Dev. Corp., 429 U.S. 252, 270-71, 270 n.21 (1977)). 
challenged, partisan motivation may often rise to the level of purposeful racial discrimination, violating both section 2 and the Fourteenth Amendment's prohibition on purposeful racial discrimination. ${ }^{134}$ But even if a court were to find that partisan considerations did not rise to that level, it must treat those motivations under the section 2 results test as evidence that the jurisdiction's policy is tenuous and therefore, under the totality of the circumstances, partisan motivation cuts in favor of finding section 2 liability.

\section{CONCLUSION}

In Shelby County v. Holder, the Chief Justice observed that "history did not end in 1965." 135 No, indeed. Contrary to the triumphalist story the Court offered in Shelby County, the United States has gone through a series of cycles in which the right to vote has expanded and contracted. The second generation of first-generation cases ${ }^{136}$ we are now seeing under the Voting Rights Act should therefore come as no surprise.

Section 2 of the Voting Rights Act expresses Congress's firm commitment to rooting out nationwide the exclusion of minority voters. Courts faced with section 2 vote denial claims should not permit states to justify restrictions on the right to vote, particularly new restrictions, on the grounds that they have only a marginal effect on turnout, can be overcome if minority citizens just put more effort into meeting the requirements, resemble the existing law in some other jurisdiction, or bear some articulable relation to efficiency or electoral integrity. The Voting Rights Act was intended to disrupt politics as usual in the service of full civic inclusion for long-excluded minority citizens, and the fact that the new restrictions often stem from that usual politics is a reason to strike them down, and not to sustain them.

${ }^{134}$ See, e.g., N.C. State Conf. of NAACP v. McCrory, 831 F.3d 204, 215 (4th Cir. 2016).

${ }^{135}$ Shelby Cty. v. Holder, 133 S. Ct. 2612, 2628 (2013).

${ }^{136}$ I describe the first-generation (vote denial), second-generation (vote dilution), and third-generation (representative decisionmaking) framework in Pamela S. Karlan, The Impact of the Voting Rights Act on African Americans: Second-and Third-Generation Issues, in Voting Rights AND REDISTRICTING IN THE UNITED STATES 121 (Mark E. Rush ed., 1998). 